ISSN 1814-1196

Научный вестник НГТУ

том 73, № 4, 2018, с. 7-26

ИНФОРМАТИКА,

ВЫЧИСЛИТЕЛЬНАЯ ТЕХНИКА

И УПРАВЛЕНИЕ

УДК 331.1:519.24 http://journals.nstu.ru/vestnik

Science Bulletin of the NSTU

Vol. 73, No. 4, 2018, pp. 7-26

\author{
INFORMATICS, \\ COMPPUTER ENGINEERING \\ AND CONTROL
}

DOI: $10.17212 / 1814-1196-2018-4-7-26$

\title{
Algorithms for estimating labour productivity prediction based on regression and dynamic models ${ }^{*}$
}

\author{
A.ZH. ABDENOV ${ }^{a}$, A.A. ABDENOVA ${ }^{b}$, A.A. MUKHANOVA ${ }^{c}$ \\ 010000, KZ, Astana, 2, K. Satpaev Street, Eurasian National University \\ aamirlan21@gmail.com ${ }^{b}$ aliyastana@gmail.com cayagoz198302@mail.ru
}

\begin{abstract}
Gross domestic product is one of the most important indicators of the national accounts system. It characterizes the final result of productive activity of domestic economic units and measures the value of goods and services produced by these units in the country for a certain period of time for final use. The paper considers an algorithm for constructing a linear stationary model in terms of the state space for describing behaviour and predicting labour productivity state depending on the capitallabour ratio and labour costs, instead of describing the object given by the three-factor non-linear Cobb-Douglas model. In addition to a general construction of a dynamic model the algorithm includes the description of the procedures in the form of recursive formulae allowing calculation of variance magnitudes for the dynamic noise, the measuring system noise and the initial state of the investigated object behaviour on the basis of statistical time series data related to labour productivity. An example shows that the proposed model provides more efficient prediction estimates of labour productivity values compared with the prediction estimates calculated using a three-factor non-linear regression model. The numerical calculations of the accuracy of prediction estimates were made using an absolute percentage error and the Teil formula for both the three-factor Cobb-Douglas model and the model in the form of the state space. The calculations showed more accurate prediction estimates and more adequate filtering estimates for the model in terms of the state space.
\end{abstract}

Keywords: Cobb-Douglas model, three-factor model, dynamic model, state space, noise variance, Kalman filter, absolute percentage error, Teil formula

\section{INTRODUCTION}

In macroeconomic interpretation the gross domestic product (GDP) is one of the most significant indicators in the system of national accounts, it characterizes the final result of the productive activity of economic units-residents and measures the cost of goods and services produced in the country for a certain period of time by these units for the final use. The level of economic development of a country and general welfare of the nation depend on GDP.

\footnotetext{
* Received 22 February 2018.
} 
However, a more qualitative and accurate measure showing the material prosperity of the citizens of any country compared to GDP is the GDP calculated per capita. Therefore, the study of GDP volume and dynamics using mathematical models is an important subject of statistical analysis.

However, a more qualitative and accurate measure showing the material prosperity of the citizens of any country compared to GDP is the GDP calculated per capita. Therefore, the study of GDP volume and dynamics using mathematical models is an important subject of statistical analysis.

For this purpose it is necessary to solve at least two problems: the first is to determine the

dependence of the GDP on the most significant factors to get a high enough adequacy with statistical data; the second is to construct efficient GDP prediction estimates which would allow predicting economic development of the country for the years to come.

For this purpose it is necessary to solve at least two problems: the first is to determine the dependence of the GDP on the most significant factors to get a high enough adequacy with statistical data; the second is to construct efficient GDP prediction estimates which would allow predicting economic development of the country for the years to come.

To solve the first problem, the significant factors are: the amount of capital assets in production and the number of employees engaged in the production. So for US manufacturing industry of 30-s the economists Ch. Cobb and P. Douglas constructed the two-factor nonlinear regression dependence for the industrial production yield [1]:

$$
Y=A \cdot K^{\alpha} \cdot L^{1-\alpha},
$$

where $Y$ is the industrial production yield in terms of cost; $L$ is the number of employees engaged in production; $K$ is the amount of capital assets used in production; $A, \alpha$ are the model parameters determined by statistical data.

In this case, the scale parameter $A$ characterizes the model's degree of uncertainty from the point of view of completeness of the factors affecting an yield variable. It is noted in [1] that the alue of this parameter is close to 1, that suggests that the capital-labor ratio and the number of employees factor sufficiently accurately determine the production yield.

At the same time, the author of [1] for the purpose of decreasing the degree of uncertainty of the model (1) proposed to include in the model the new factor - the labour cost of the workers engaged in the economy. Using such factor in the model is indeed very important owing to the fact that salaries are the main incentive for employees to work. As a result, the author of [1] proposed a new formula in the form of a three-factor nonlinear regression dependency:

$$
\frac{Y}{L}=A^{*}\left(\frac{K}{L}\right)^{\alpha}\left(\frac{S}{L}\right)^{\beta} \text {, }
$$

where $S$ is the new factor characterizing the labor cost of workers engaged in the economy; $A^{*}$ is the new scale factor; $\alpha$ is the elasticity coefficient for the capital- 
labor; $\beta$ is the elasticity coefficient for the workers labor cost function. Other variables of expression (2) are explained above.

The author of [1] noted that formulae (1) and (2) do not always adequately reflect the true dependence of labor productivity on the capital-labor ratio and the workers' labour cost. For example, in the field of education other approaches and formulae based on other factors should be used. In this paper, we would like to mention two more drawbacks in models (1) and (2): first, these models are based on statistical data that are random, and the GDP calculations can be distorted; secondly, it is not possible to use these formulae for calculating the industrial production yield prediction estimates because of the regression formulae nonlinearity and the need for accurate calculations of predicted values for other factors included in the formulae (1) and (2).

To solve the second problem, concerning calculation of the labour productivity prediction estimate, we propose in this paper to use linear stationary models in terms of state space (SS). Therefore, the authors describe an algorithm for constructing the dynamic models in terms of SS on the basis of statistical data taking into account stochastic nature of all factors presented in the three-factor nonlinear regression model for calculation of the prediction estimates and the most reliable filtered estimates for the labour productivity.

It is practically not possible to make absolutely accurate prediction estimates for TS values. Therefore, an important task is to study the accuracy characteristics of prediction and filtered estimates for various types of models. The reliability of the chosen model to predict future TS values is assessed by periodic comparison of actual and predicted values, and by possibility of adjusting the prediction estimates for TS. The selected model type should provide the most accurate prediction estimate, as only in this case, the prediction estimate would be useful. Criteria for evaluating the accuracy of predicted TS values on the basis of different model types have to consider the predicted values scatter. The predicted values scatter is determined by the difference between the actual observed values and prediction estimates values calculated on the basis of the considered models.

Degrees of reliability and quality of TS values prediction estimates are calculated using different indicators. One of such quality indicators is the absolute percentage error (APE):

$$
\mathrm{APE}=\left|\frac{x_{k}-\bar{x}_{k}}{x_{k}}\right| 100 \%,
$$

where $x_{k}$ is the real actual TS value; $\hat{x}_{k}$ is the predicted TS value.

Error coefficient for the predicted estimates values as compared with the actual TS values can also be calculated using Teil formula [2]:

$$
L=\frac{\left[\frac{1}{n} \sum_{k=1}^{n}\left(x_{k}-\hat{x}_{k}\right)^{2}\right]^{\frac{1}{2}}}{\left[\frac{1}{n} \sum_{k=1}^{n} \hat{x}_{k}^{2}\right]^{\frac{1}{2}}+\left[\frac{1}{n} \sum_{k=1}^{n} x_{k}^{2}\right]^{\frac{1}{2}}} .
$$


The closer the Teil coefficient is to zero, the closer are the corresponding values in the predicted and actual TS. The calculated coefficient $L$ proved to work for both the statistical and qualitative retrospective predictions.

\section{FORMULATION OF THE PROBLEM}

It is well known from scientific literature the two-factor regression relationship between the labour productivity $\frac{Y}{L}$ and the capital-labour ratio $\frac{K}{L}[3]$. This dependence is known as Cobb-Douglas equation. The model takes into account two most important economic factors - capital assets and labour. However, the main motivation to work is the possibility to gain income in the form of remuneration of labour. Thus, the three-factor Cobb-Douglas model is considered in [1] and takes into account person and society motivation through the remuneration of labour factor. The author of paper [1] uses the following derivatives of the abovementioned economic factors: $\frac{Y}{L}$ - the labour productivity; $\frac{K}{L}-$ the capital-labour ratio with the elasticity coefficient $0<\alpha<1$ and for the three-factor model one more factor is added $\frac{S}{L}$ - the amount of remuneration with the elasticity coefficient $0<\beta<1$. As a result new nonlinear regression dependence of productivity on the capitallabor ratio and remuneration amount was derived in [1].

In practice, all annual values of the factor variables may be conveniently presented in the form of TS values. For example, paper [1] provides for annual statistical data on $Y, L, K, S$ taken from [4]. Using these data, the author of paper [1] calculated the unknown scale factor $A^{*}$, the capital-labor ratio elasticity coefficient $\alpha$, the remuneration of labour elasticity coefficient $\beta$. The following values were obtained: $A^{*}=0.9911, \alpha=0.5196, \beta=0.5303$.

Using the equation (2) and statistical TS data on capital-labour ratio, on remuneration of labour, and the calculated values of the coefficients $A^{*}, \alpha, \beta$ it is possible to calculate the labour productivity prediction estimate. However, the reliability of such prediction estimate is low owing to several reasons: first, the statistical uncertainty of $Y, L, K, S$ data is not taken into account; second, the known values for $\frac{Y}{L}$ TS variance are not used; third, there is no in the equation (2) the variable representing the labour productivity change rate which could have been a basic element enabling prediction estimate calculation for the investigated object.

Therefore, for calculation of the most reliable labour productivity prediction estimates the authors propose using a linear stationary model in terms of state space (SS). 


\section{ETHOD FOR CONSTRUCTING LINEAR STATIONARY MODEL IN TERMS OF SS}

Let us consider a linear stationary model in terms of SS as:

$$
\begin{gathered}
\dot{x}(t)=a \cdot x(t)+b \cdot u(t)+c \cdot z(t)+d+w(t), \quad x\left(t_{1}\right)=\bar{x}_{1}, \\
y\left(t_{k+1}\right)=x\left(t_{k+1}\right)+v\left(t_{k+1}\right), \quad t_{k} \in\left[t_{1}, t_{N}\right], \quad k=1,2, \ldots, N,
\end{gathered}
$$

where $\left\{x(t) \approx f(t)=\frac{Y(t)}{L(t)}, \quad u(t)=k(t)=\frac{K(t)}{L(t)}, \quad z(t)=s(t)=\frac{S(t)}{L(t)}, \quad t \in\left[t_{1}, t_{N}\right]\right\}$; $\left\{x\left(t_{k+1}\right) \approx f\left(t_{k+1}\right)=\frac{Y\left(t_{k+1}\right)}{L\left(t_{k+1}\right)}, \quad y\left(t_{k+1}\right) \approx x\left(t_{k+1}\right), \quad k=1,2, \ldots, N\right\} ; \bar{x}_{1}$ is the expected mean of the initial state. To clarify the economic nature of the variables in the model (5), (6) we are going to consider below all other variables after some transformation of the three-factor model (2).

\subsection{TRANSFORMATION OF THE THREE-FACTOR MODEL INTO THE MODEL IN TERMS OF SS}

Let use new notations for the variables in equation (2)

$$
\left\{\frac{Y_{i}}{L_{i}}=f_{i}, \quad \frac{K_{i}}{L_{i}}=k_{i}, \quad \frac{S_{i}}{L_{i}}=s_{i}, \quad i=1,2, \ldots, N\right\} .
$$

Then the equation (2) can be rewritten as:

$$
f_{i}=A^{*} \cdot\left(k_{i}\right)^{\alpha} \cdot\left(s_{i}\right)^{\beta}, \quad i=1,2, \ldots, N .
$$

Let us take a logarithm of both sides of (7). We obtain the following equation:

$$
\log \left(f_{i}\right)=\log \left(A^{*}\right)+\alpha \log \left(k_{i}\right)+\beta \log \left(s_{i}\right), \quad i=1,2, \ldots, N .
$$

Let us introduce additional notations: $f f_{i}=\log \left(f_{i}\right) ; a=\log \left(A^{*}\right) ; \quad k k_{i}=\log \left(k_{i}\right)$; $s s_{i}=\log \left(s_{i}\right), \quad i=\overline{1, N}$.

Using the last notations the expression (8) is written as:

$$
f f_{i}=a+\alpha \cdot k k_{i}+\beta \cdot s s_{i}, \quad i=1,2, \ldots, N .
$$

The relation (9) is written in a purely deterministic form without considering the random nature of TS statistical data $\left\{f f_{i}, i=1,2, \ldots, N\right\},\left\{k k_{i}, i=1,2, \ldots, N\right\}$, $\left\{s s_{i}, \quad i=1,2, \ldots, N\right\}$.

In order to take into account the random nature of the labour productivity TS behaviour we will use the stationary model in terms of SS that takes into account the object dynamics noise in additive form, assuming that they are white and Gaussian, the initial conditions obey Gaussian law and that the observation noise is also white and Gaussian. 
First, we introduce the notion of TS data change rate for the values of labour productivity. Let us denote the average change rate of the output values of measuring system observing behaviour of the investigated object as $\mu_{\mathrm{cp}} \approx \frac{\Delta f}{\Delta t}=\frac{\Delta x}{\Delta t}$ in the range from $t_{i}$ to $t_{i}+\Delta t$, where $\Delta f=f\left(t_{i}+\Delta t\right)-f\left(t_{i}\right)$. Using $\left\{\Delta t=t_{i+1}-t_{i}=1, \quad i=\overline{1, N-1}\right\}$ and assuming that $\left\{x\left(k_{i}\right) \approx f\left(k_{i}\right), \quad i=\overline{1, N}\right\}$ we can write the model in terms of SS taking into account stochastic effects on TS data in (5), (6):

$$
\dot{x}(t) \approx \frac{x\left(t_{i+1}\right)-x\left(t_{i}\right)}{t_{i+1}-t_{i}}=a \cdot x(t)+\alpha \cdot u(t)+\beta \cdot z(t)+d+w(t), \quad x\left(t_{1}\right)=\bar{x}_{1},
$$

and considering that $\Delta t=1$ the equation (10) takes the form

$$
\begin{array}{ll}
x\left(t_{i+1}\right)-x\left(t_{i}\right)=a \cdot x(t)+\alpha \cdot u(t)+\beta \cdot z(t)+d+w(t), & x\left(t_{1}\right)=\bar{x}_{1}, \\
x\left(t_{i+1}\right)=(1+a) \cdot x\left(t_{i}\right)+b \cdot u\left(t_{i}\right)+c \cdot z\left(t_{i}\right)+d+w\left(t_{i}\right), & x\left(t_{1}\right)=\bar{x}_{1},
\end{array}
$$

or

$$
\begin{gathered}
x\left(t_{i+1}\right)=a_{1} \cdot x\left(t_{i}\right)+b \cdot u\left(t_{i}\right)+c \cdot z\left(t_{i}\right)+d+w\left(t_{i}\right), \quad x\left(t_{1}\right)=\bar{x}_{1}, \\
y\left(t_{i+1}\right)=x\left(t_{i+1}\right)+v\left(t_{i+1}\right), \quad t_{i} \in\left[t_{1}, t_{N}\right], \quad i=1,2, \ldots, N,
\end{gathered}
$$

where $t_{i}$ is the discrete point in time; $x\left(t_{i}\right)$ is the discrete value of the investigated object state characterizing the labour productivity; $x\left(t_{1}\right)=\bar{x}_{1}$ is the initial object's state corresponding to the labour productivity expected mean at the start time point $t_{1}$ and assuming to follow Gaussian law with unknown variance $P\left(t_{1}\right)=P_{1} ; w\left(t_{i}\right)$ is the white Gaussian sequence with zero mean and unknown variance $Q$; $\left\{u\left(t_{i}\right), i=\overline{1, N}\right\}$ is the first input sequence of discrete values characterizing the capital-labour ratio with the elasticity coefficient $0<\alpha<1 ;\left\{z\left(t_{i}\right), \overline{1, N}\right\}$ is the second input sequence of discrete values characterizing the remuneration of labour with the elasticity coefficient $0<\beta<1 ;\left\{y\left(t_{i}\right)=f\left(t_{i}\right), i=\overline{1, N}\right\}$ is the sequence of discrete values of the measuring system output; $\left\{v\left(t_{i}\right), i=\overline{1, N}\right\}$ is the white Gaussian sequence with zero mean and unknown variance $R ; a_{1}, \alpha, \beta, d$ are the unknown coefficients in the dynamics model (11); $N$ is the sampling size.

Given that all statistical TS data $\left\{f f_{i}, i=1,2, \ldots, N\right\},\left\{k k_{i}, i=1,2, \ldots, N\right\}$, $\left\{s s_{i}, \quad i=1,2, \ldots, N\right\}$ are random in nature we can include the aggregate randomness in the additive term of the object's dynamic noise $\left\{w\left(t_{i}\right), i=1,2, \ldots, N-1\right\}$, while all unaccounted factors of the model (11) we can include in the free additive term $d$.

Thus, the function (2) is converted to the linear model in terms of SS, for which it is proposed to use the following algorithm for recursive calculation of all variances [5] necessary for solving equations according to the Kalman filter scheme [6], and calculation of the coefficients $a_{1}, \alpha, \beta, d$ in the model (11) using the least squares method (LSM). 


\subsection{CALCULATION OF NOISE VARIANCE ESTIMATES FOR DYNAMICS OF OBJECT AND MEASURING SYSTEM}

In order to solve the problem of estimating the state and predicting the main indicator of the dynamic system, the Kalman filter scheme is used for which the model's parameters estimates as well as characteristics of the noise of the dynamics and the measuring system should be known. Therefore, in this Section, for building one-dimensional stochastic linear stationary model in terms of SS, we will consider the recursive algorithm for estimating the variances of noise of the object dynamics and the measuring system on the basis of discrete observations data of the given sampling size.

We will represent the model of the investigated object in the continuousdiscrete form (5), (6). Note that the simplified differential equation, without considering the two input effects on the state of the investigated object in the ratio (5) and given the loose requirements to the accuracy of the model on a given time interval, corresponds to the following averaged differential equation:

$$
\dot{\bar{x}}(t)=a \cdot \bar{x}(t)
$$

with the initial condition

$$
x\left(t_{1}\right)=\bar{x}_{1}, \quad t \in\left[t_{1}, l_{N}\right] .
$$

The differential equation (13) can be approximated by the difference scheme

$$
\bar{x}\left(t_{k+1}\right)=\mu \cdot \bar{x}\left(t_{k}\right) .
$$

In general, when the equation (13) on the interval is of a vector type and $\mathbf{A}$ is the matrix of $(n \times n)$ size, then (13) can be written in the form:

$$
\dot{\overline{\mathbf{x}}}(t)=\mathbf{A} \cdot \overline{\mathbf{x}}(t) .
$$

The condition for building a stable difference equation depends on stability of the matrix $\mathbf{A}$ and can be found in [7].

Let the investigated object model on the given time interval $\left[t_{1}, t_{N}\right]$ be represented by the model in terms of SS as:

$$
\begin{gathered}
x\left(t_{k+1}\right)=\mu \cdot x\left(t_{k}\right)+w\left(t_{k}\right), \\
x\left(t_{1}\right)=\bar{x}_{1}, \\
y\left(t_{k+1}\right)=x\left(t_{k+1}\right)+v\left(t_{k+1}\right), \quad k=\overline{0, N-1},
\end{gathered}
$$

where for the stability reason we assumed that $\mu=0.97 ; x\left(t_{k}\right)-$ is the true value of the investigated object state, $w\left(t_{k}\right)$ - is the white Gaussian sequence with zero mean and unknown variance $E\left[\left(w\left(t_{k}\right)^{2}\right]=\sigma_{w}^{2}\left(t_{N} \mid t_{N}\right)=Q ; y\left(t_{k}\right)-\right.$ are the measuring system discrete output values; $v\left(t_{k}\right)$ - is the random sequence with the unknown mean $E\left[\left(v\left(t_{k}\right)\right]=q\right.$ and the unknown variance $E\left[\left(v\left(t_{k}\right)\right)^{2}\right]=$ 
$=\sigma^{2}\left(t_{N} \mid t_{N}\right)=R ; \bar{x}\left(t_{1}\right)-$ is the initial state with the expected mean $\bar{x}_{1}$ and the unknown variance $P_{1}$.

For estimation of the mean value we form the sequence of pseudomeasurements in the following way:

$$
v\left(t_{k}\right)^{(2)}=y\left(t_{k}\right)-y\left(t_{k-1}\right), \quad k=2,3, \ldots N .
$$

The variables' superscripts mean the number of measurements used for the particular variable formation. Let us suppose that $q$ has constant value. It means that the following equation can be written:

$$
v\left(t_{k}\right)^{(2)}=q+\tilde{v}\left(t_{k}\right)
$$

Then the estimate for $q$, assuming its constancy, is determined as follows

$$
\hat{q}\left(t_{k} \mid t_{k}\right)=\hat{q}\left(t_{k-1} \mid t_{k-1}\right)+\frac{1}{N(k+1)} a b s\left(v\left(t_{k}\right)^{(2)}-\hat{q}\left(t_{k-1} \mid t_{k-1}\right)\right), \quad k=\overline{2, N},
$$

with the initial condition $\hat{q}\left(t_{1} \mid t_{1}\right)=0$. Finally, $q \approx \hat{q}\left(t_{N} \mid t_{N}\right)$.

One can consider the expression for discrepancy (term by P. Eickhoff [8]) of a simplified three-point filter in the form:

$$
v\left(t_{k}\right)^{(3)}=y\left(t_{k}\right)-\frac{1}{2} y\left(t_{k-1}\right)-\frac{1}{2} y\left(t_{k-2}\right), \quad k=3,4, \ldots N .
$$

The mean value of the discrepancies: $E\left[v\left(t_{k}\right)^{(2)}\right]=q, E\left[v\left(t_{k}\right)^{(3)}\right]=\frac{3}{2} q$.

It was shown in $[5,9]$ that $E\left[\left(v\left(t_{k}\right)^{(3)}-\frac{3}{2} q\right)\left(v\left(t_{k}\right)^{(2)}-q\right)\right]=\frac{1}{2} \sigma_{w}^{2}$. Then the sequence for measurement of the variance $\sigma_{w}^{2}$ is determined in the following way:

$$
y\left(t_{k}\right)^{(w)}=2\left(v\left(t_{k}\right)^{(3)}-\frac{3}{2} \hat{q}\left(t_{k} \mid t_{k}\right)\right)\left(v\left(t_{k}\right)^{(2)}-\hat{q}\left(t_{k} \mid t_{k}\right)\right), \quad k=3,4, \ldots, N,
$$

and the estimate for the constant variance $\sigma_{w}{ }^{2}$ can be calculated by the formula

$$
\left.\hat{\sigma}_{w}^{2}\left(t_{k} \mid t_{k}\right)=\hat{\sigma}_{w}^{2}\left(t_{k-1} \mid t_{k-1}\right)+\frac{1}{k-1}\left(y\left(t_{k}\right)^{(w)}-\hat{\sigma}_{w}^{2}\left(t_{k-1}\right) \mid t_{k-1}\right)\right), \quad k=\overline{3, N},
$$

with the initial condition $\hat{\sigma}_{w}^{2}\left(t_{2} \mid t_{2}\right)=0$. Finally, $Q \approx \sigma_{w}^{2}\left(t_{N} \mid t_{N}\right)$.

It was shown in [5,9] that $E\left[\left(v\left(t_{k}\right)^{(2)}-q\right)^{2}\right]=2 \sigma^{2}+\sigma_{w}^{2}=2 R+Q$. Thus, the sequence:

$$
y\left(t_{k}\right)^{(v)}=\frac{1}{2}\left[\left(v\left(t_{k}\right)^{(2)}-\hat{q}\left(t_{k} \mid t_{k}\right)\right)^{2}-\hat{\sigma}_{w}^{2}\left(t_{k} \mid t_{k}\right)\right], \quad k=2,3, \ldots, N
$$


can be considered as the variance measurements sequence for which $\sigma^{2}\left(t_{N} \mid t_{N}\right)=R$, in this case the estimate, under the accepted assumption on its constancy, is calculated by the recursive formula:

$$
\hat{\sigma}^{2}\left(t_{k} \mid t_{k}\right)=\hat{\sigma}^{2}\left(t_{k-1} \mid t_{k-1}\right)+\frac{2}{k} a b s\left(y\left(t_{k}\right)^{(v)}-\hat{\sigma}^{2}\left(t_{k-1} \mid t_{k-1}\right)\right), \quad k=\overline{2, N},
$$

with the initial condition $\hat{\sigma}^{2}\left(t_{1} \mid t_{1}\right)=0$. Finally, $R \approx \sigma^{2}\left(t_{N} \mid t_{N}\right)$.

There is left to obtain the estimates for the initial state noise $P\left(t_{1}\right)$. As the estimate for the initial state noise variance we can take the estimate for the object's dynamics noise variance, i. e. $P\left(t_{1}\right)=P\left(t_{1} \mid t_{1}\right)=\hat{\sigma}_{w}^{2}\left(t_{1} \mid t_{1}\right) \approx Q$.

The discrepancies coefficients of the second terms in relationships (21), (24), (26) sometimes require some correction depending on the absolute values of discrete observations.

The efficiency of the algorithm described above will be checked on the test example using a Kalman filter algorithm for the simplified model of the form (16)(18). In this case the prediction estimates for one step $\hat{x}\left(t_{k+1} \mid t_{k}\right)$ can be calculated according to the following Kalman filter formulae:

$$
\begin{gathered}
\hat{x}\left(t_{k+1} \mid t_{k}\right)=\mu \cdot \hat{x}\left(t_{k} \mid t_{k}\right), \\
\hat{x}\left(t_{1} \mid t_{1}\right)=y\left(t_{1}\right), \\
\hat{x}\left(t_{k+1} \mid t_{k+1}\right)=\hat{x}\left(t_{k+1} \mid t_{k}\right)+K\left(t_{k+1}\right)\left(y\left(t_{k+1}\right)-\hat{x}\left(t_{k+1} \mid t_{k}\right)\right),
\end{gathered}
$$

while the filter amplification coefficient, the variances for prediction and filtered estimates are calculated with the formulae:

$$
\begin{gathered}
K\left(t_{k+1}\right)=\frac{P\left(t_{k+1} \mid t_{k}\right)}{P\left(t_{k+1} \mid t_{k}\right)+\hat{\sigma}^{2}\left(t_{k+1} \mid t_{k+1}\right)}, \\
P\left(t_{k+1} \mid t_{k}\right)=\mu^{2} \cdot P\left(t_{k} \mid t_{k}\right)+\hat{\sigma}_{w}^{2}\left(t_{k+1} \mid t_{k+1}\right), \\
P\left(t_{1} \mid t_{1}\right)=\hat{\sigma}_{w}^{2}\left(t_{1} \mid t_{1}\right), \\
P\left(t_{k+1} \mid t_{k+1}\right)=\left(1-K\left(t_{k+1}\right)\right) P\left(t_{k+1} \mid t_{k}\right), k=\overline{0, N-1} .
\end{gathered}
$$

Thus, the algorithm for estimating the noise variances of the dynamics and measuring system with subsequent application of the Kalman filtering involves the following steps:

1) formation of the simplified filter discrepancies sequences $v\left(t_{k}\right)^{(2)}$ and $v\left(t_{k}\right)^{(3)}$ according to the expressions (19) and (22);

2) estimation of the mean value of the increase of the measurements sequence terms by $q$ according to (21); 
3) construction of the centered discrepancies values products according to the formula (23);

4) estimation of the model's dynamics variance $\sigma_{w}^{2}$ according to the expression (24);

5) construction of the measuring system's noise variance discrepancies sequences according to the formula (25);

6) estimation of the measuring system's noise variance $\sigma^{2}$ based on (26);

7) estimation of the initial state noise variance by the equation (32);

8 ) construction of the considered entities in the form of the filtered estimates using the relations (27)-(33).

\subsection{EXAMPLE 1. TESTING THE ALGORITHM ON TEST DATA}

Let us consider the model (16)-(18). Let there be a sequence of random variables $\left\{w\left(t_{k}\right), \quad k=1, \ldots, 51\right\}$ with the zero mean and the variance $Q=0.1$ and the parameter $\mu=0.9$. Let there be also the sequence $v\left(t_{k}\right)$ with the constant mean $q=0.2$ and the variance $R=0.3$. Assuming $\vec{x}\left(t_{1}\right)=3$ and using the generated random sequences $w\left(t_{k}\right), v\left(t_{k}\right)$ together with the formulae (16), (18) we obtain the sequence $\left\{y\left(t_{k}\right), \quad k=1, \ldots, 51\right\}$. To the obtained sequence $\left\{y\left(t_{k}\right), \quad k=1, \ldots, 51\right\}$ we apply estimation algorithms for: the measuring system's noise expected mean, the object's state and the measuring system's noise variances, in addition we calculate the coefficient $\hat{\mu}$ using the least-squares method (LSM). The following estimates were obtained after the calculations: $q \approx 0.17, Q \approx 0.11, R \approx 0.33, \hat{\mu} \approx 0.89$.

The results of modeling the measuring system output, the prediction and filtered estimates, with and without considering the systematic error of the measuring system output, are represented on fig. 1 and fig. 2, correspondingly. It can be seen from the graphs that the proposed algorithm allows estimating the constant mathematical mean for the measuring system's output sequence and to monitor the state in the form of the filtered estimates.

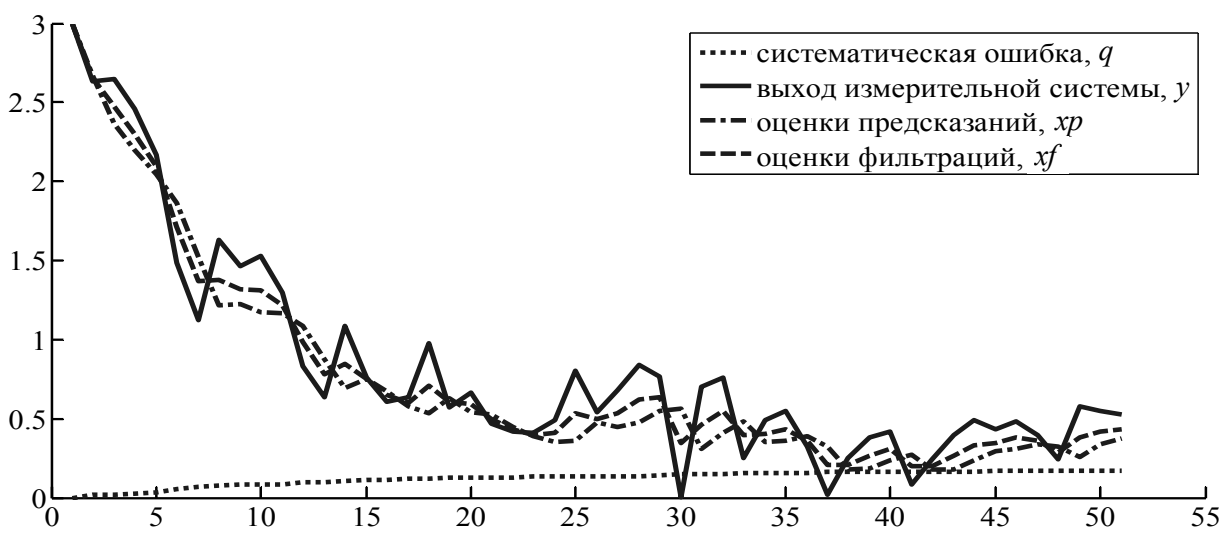

Fig. 1. The results of modeling the measuring system output, prediction and filtered estimates taking into account a systematic error of the measuring system output 


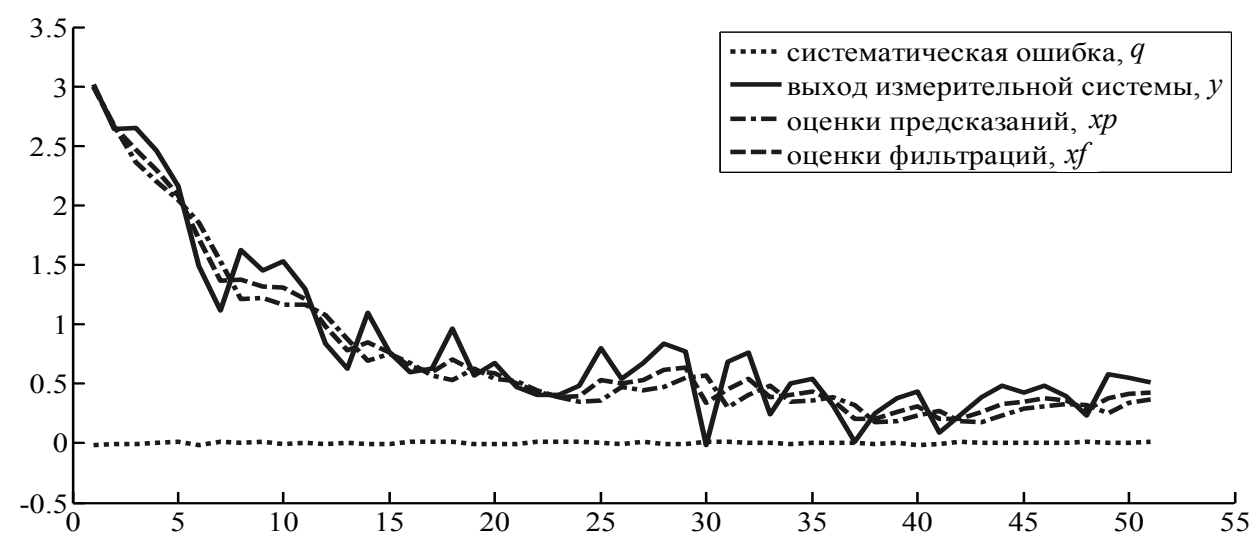

Fig. 2. The results of modeling the measuring system output, prediction and filtered estimates taking into account a systematic error of the measuring system output

Thus, in this section the recursive algorithm using the Kalman filter equations for calculation of the object's dynamics and the measuring system's noise variances is considered for the one-dimensional case. The algorithm allows calculating the variances in a recursive form based on the measuring system output data without any consideration of particular model parameters. The algorithm has been checked on the test data. In the case of a multidimensional system equations for each dimension should be considered separately.

\subsection{ALGORITHM FOR CONSTRUCTING A STATIONARY MODEL IN TERMS OF SS}

The algorithm for constructing the model in terms of SS consists of the following steps:

1. Let us choose one significant factor, then with respect to the factor's state space variable we consider TS sequences of two input and one output data variables $\left\{f f\left(t_{i}\right), u\left(t_{i}\right)=k k_{i}, z\left(t_{i}\right)=s s\left(t_{i}\right), i=\overline{1, N}\right\}$ and $\left\{y\left(t_{i}\right)=f\left(t_{i}\right), i=\overline{1, N}\right\}$, correspondingly.

2. Now, assuming that the investigated process state change depends on the time variable $t$, the investigated object's dynamics change rate $x\left(t_{i}\right)$ can be expressed as the finite-difference relation (11) taking into account initial conditions, two input factors and additive interference affecting the object's behaviour. Adding to consideration the measuring system equation (12) the model in terms of SS can be written in the form of (11) and (12).

The equations (11), (12) represent the investigated object's model in terms of $\mathrm{SS}$, the model still having unknown coefficients $a_{1}, \alpha, \beta, d$ and the unknown variances of the dynamics noise $Q$, the measuring system noise $R$ and the initial state noise $P\left(t_{1}\right)=P_{1}$. We have only two inputs, one output data and the sampling size.

3. Using the algorithm described in 3.2 it is possible using only the measuring system output sequences and the given sampling size to obtain estimates for the investigated object dynamics error variance $Q=\hat{Q}$, the measuring system error variance $R=\hat{R}$ and the initial state error variance $P\left(t_{1}\right)=\hat{P}_{1}$. 
4. Assuming that $\left\{x\left(t_{i}\right) \approx y\left(t_{i}\right), \quad i=\overline{1, N}\right\}$, considering known data on the two input sequences and one output sequence, and using the LSM [3] it is possible to obtain estimates for the dynamics model coefficients $\left(a_{1}, \alpha, \beta, d\right)$ of the equation (11).

5. The solution to the problem of estimating the investigated object state on the basis of the Kalman filter equations [5, 6] for the model (11), (12) makes it possible to obtain the prediction estimates $\hat{x}\left(t_{i+1} \mid t_{i}\right)$ and the most reliable filtered estimates $\hat{x}\left(t_{i+1} \mid t_{i+1}\right)$ concerning the state variable $\left\{x\left(t_{i+1}\right), \quad t_{i} \in\left[t_{1}, t_{N}\right], i=\overline{1, N}\right\}$.

Let us test the described algorithm using the data from ref. [1].

\section{Example 2}

Let the process at some interval $\left[t_{1}, t_{N}\right]$ be described by the non-linear CobbDouglas [1] model of the type $f=A^{*} \cdot k^{\alpha} \cdot s^{\beta}$ where $f$ is the output signal, $\mathrm{k}, \mathrm{s}$ are two input signals. It is required to compare accuracy characteristics of the prediction estimates obtained by the non-linear regression model (2) and the linear stochastic model in terms of SS (11), (12).

Solution. For the considered example the estimates for the model (2) coefficients were obtained with LSM for the TS data $\left\{f\left(t_{i}\right), k\left(t_{i}\right), s\left(t_{i}\right) \quad t_{i} \in\left[t_{1}, t_{N}\right], i=\overline{1, N}\right\}$. The initial observations data are brought together in Table 1 .

Table 1

\begin{tabular}{|l|c|c|c|c|c|}
\hline \multirow{2}{*}{ Macroeconomic indicators } & \multicolumn{5}{c|}{ Year } \\
\cline { 2 - 6 } & 2000 & 2001 & 2002 & 2003 & 2004 \\
\hline Nominal GDP, bln., a.u. $\left(Y_{i}\right)$ & 7305.6 & 8943.6 & 10817.4 & 13243.2 & 17048.1 \\
\hline Labour force engaged in economy $\left(L_{i}\right)$ & 64.5 & 65.0 & 65.6 & 66.0 & 66.4 \\
\hline Fixed assets cost $\left(K_{i}\right)$ & 16.605 & 20241 & 24431 & 30329 & 32541 \\
\hline Average monthly salary, a.u. $\left(S_{i}\right)$ & 2223.4 & 2240.4 & 4360.3 & 5498.5 & 6739.5 \\
\hline
\end{tabular}

Table 1 (continued)

\begin{tabular}{|l|c|c|c|c|c|}
\hline \multirow{2}{*}{ Macroeconomic indicators } & \multicolumn{5}{|c|}{ Year } \\
\cline { 2 - 6 } & 2005 & 2006 & 2007 & 2008 & 2009 \\
\hline Nominal GDP, bln., a.u. $\left(Y_{i}\right)$ & 21625.4 & 26880.5 & 33111.4 & 41668.0 & 39064 \\
\hline $\begin{array}{l}\text { Labour force engaged in econo- } \\
\text { my }\left(L_{i}\right)\end{array}$ & 66.8 & 67.2 & 68.0 & 68.5 & 68.7 \\
\hline Fixed assets cost $\left(K_{i}\right)$ & 38368 & 43823 & 54246 & 64553 & 66489.6 \\
\hline Average monthly salary, a.u. $\left(S_{i}\right)$ & 8554.9 & 10633.9 & 13593.4 & 17290.1 & 20748.1 \\
\hline
\end{tabular}

They were obtained in [1] using the LSM and the data from [4] the coefficients of the three-factor Cobb-Douglas formula (2): $A^{*}=0.9911 ; \alpha=0.5196$; $\beta=0.5303$. In this case, firstly, the coefficients values are consistent with TS data concerning the GDP, the labour force engaged in economy and the fixed assets cost but the TS data concerning the average monthly salary form the Table 1 are not 
consistent with the calculated values of the coefficients. Therefore, the data that correspond to the calculated values of the coefficients were reconstructed by solving the inverse problem, putting it in more details, by recalculating the TS data on the average monthly salary using the calculated coefficients and the TS data on the GDP, the labour force engaged in economy and the fixed assets cost. The calculated TS data for the average monthly salary are represented in Table 1. Secondly, in [1] the author notes that the data in the table are of stochastic nature and the coefficients estimates are also approximate owing to their stochastic nature.

The three-factor Cobb-Douglas formula reflects relatively roughly the dependence of the labour productivity on the capital-labor ratio, the amount of labor force engaged in economy and the labour cost. And using formula (2) for the GDP (or the labour productivity) prediction leads to a rough estimate. That is why we suggest using the linear stationary models in terms of SS for calculation of prediction estimates. The model constructed in terms of SS and application of the Kalman filter scheme allow calculating more accurate prediction estimates for the labor productivity and corrected and more reliable filtered estimates for the labour productivity. It should be noted that all variables included in the model (11), (12) are interconnected and application of the Kalman equations for prediction estimates allows correcting the estimates and obtaining filtered estimates as more reliable estimates compared with the prediction estimates for labour productivity calculated using the non-linear regression model.

But in order to use the Kalman filter equations we have to know the dynamic model (11) parameters, the dynamic model variance estimate $(Q)$, the measuring system model variance estimate $(R)$, and the initial state variance $\left(P\left(t_{1}\right)\right)$. Using the recursive formulae (24), (26), (32) from the paragraph 3.2 one can calculate estimates for the investigated object's dynamics error variance $Q$, for the measuring system error variance $R$ and for the initial state error variance $P\left(t_{1}\right)=P_{1}$.

It should be noted that it is possible to use various model types in terms of SS. For instance, the following types can be considered:

$$
x(t+1)=a_{1} \cdot x(t)+b \cdot u(t)+c \cdot z(t)+w(t), x(1)=\bar{x}_{1},
$$

or the model of the type

$$
x(t+1)=a_{1} \cdot x(t)+b \cdot u(t)+c \cdot z(t)+d+w(t), x(1)=\bar{x}_{1} .
$$

The linear stationary model in terms of SS (34) reflects the dynamics behavior depending on two input signals, although the ivestigated object's dynamics behavior is also affected by other factors too. Therefore, in our opinion, the model in terms of SS (35) more adequately describes the behaviour of the investigated object. More adequate contribution of two input factors TS values on the GDP value is reflected in the values of the weight coefficients $a_{1}, b, c, d$.

For instance, the values of the unknown coefficients in the model (34) are: $a_{1}=0.3251 ; b=0.6419 ; c=-0.0525$. As one can see, there is no proportionality between the contributions of input factors to the investigated object's state dynamics change that is also reflected in the values of weight coefficients which are very different $b$ and $c$. 
The calculated using LSM values of the unknown coefficients in the model (35) are: $a_{1}=0.5021 ; b=0.3692 ; c=0.0186 ; d=0.408$. In model (35) the first input signal makes significant contribution, the weight coefficient is $b$, the second input signal has lesser contribution, the weight coefficient is $c$, and contribution of the other unaccounted factors is of the order of the free parameter $d=0.408$. . The calculated values of the variances for the model (11), (12) in terms of SS concerning the logarithms of TS data for the labour productivity, the capital-labour ratio and the labour remuneration are: $Q=0.0078, R=0.042878, P\left(t_{1}\right)=0.0078$. The logarithms of actual TS data for the labour productivity $\left(f f_{i}\right)$, the capital-labour ratio $\left(k k_{i}\right)$, the labour remuneration $\left(s s_{i}\right)$ are represented in Table 2, where the values are for the RF Crimean region for years 2000-2014.

Table 2

\begin{tabular}{|l|c|c|c|c|c|}
\hline \multirow{2}{*}{ Macroeconomic indicators } & \multicolumn{5}{|c|}{ Year } \\
\cline { 2 - 6 } \multicolumn{1}{|c|}{1} & 2 & 3 & 4 & 5 \\
\hline Labour productivity $\left(f f_{i}\right)$ & 4.7297 & 4.9243 & 5.1053 & 5.1379 & 5.2010 \\
\hline Capital-labour ratio $\left(k k_{i}\right)$ & 5.4518 & 5.6752 & 5.7946 & 5.9642 & 6.1015 \\
\hline Average monthly salary, a.u. $\left(s s_{i}\right)$ & 3.5940 & 3.7421 & 3.8795 & 4.0285 & 4.6998 \\
\hline
\end{tabular}

Table 2 (continued)

\begin{tabular}{|l|c|c|c|c|c|}
\hline \multirow{2}{*}{ Macroeconomic indicators } & \multicolumn{5}{|c|}{ Year } \\
\cline { 2 - 6 } \multicolumn{1}{|c|}{} & 6 & 7 & 8 & 9 & 10 \\
\hline Labour productivity $\left(f f_{i}\right)$ & 5.3180 & 5.4001 & 5.5848 & 5.7095 & 5.7720 \\
\hline Capital-labour ratio $\left(k k_{i}\right)$ & 6.1740 & 6.3056 & 6.4891 & 6.5977 & 6.7267 \\
\hline Average monthly salary, a.u. $\left(s s_{i}\right)$ & 4.9465 & 5.1316 & 5.4285 & 5.6220 & 5.6491 \\
\hline
\end{tabular}

Table 2 (continued)

\begin{tabular}{|l|c|c|c|c|c|}
\hline \multirow{2}{*}{ Macroeconomic indicators } & \multicolumn{5}{|c|}{ Year } \\
\cline { 2 - 6 } & 11 & 12 & 13 & 14 & 15 \\
\hline Labour productivity $\left(f f_{i}\right)$ & 5.9211 & 6.0120 & 6.1504 & 6.2145 & 6.2959 \\
\hline Capital-labour ratio $\left(k k_{i}\right)$ & 6.8334 & 6.9402 & 7.0749 & 7.1936 & 7.2354 \\
\hline Average monthly salary, a.u. $\left(s s_{i}\right)$ & 5.7479 & 5.7613 & 5.8874 & 6.0272 & 6.0223 \\
\hline
\end{tabular}

Now, basing on the TS data for the all three factors and the sampling size $N=15$ let us generate the "real" data for three future years according to the following algorithm. For the all three TS we calculate pseudo-differences (i.e. generating pseudo-numbers similar to pseudo-random numbers as an algorithm generating the sequence of numbers which are almost independent of each other and obey a given distribution law) using the formulae:

$$
\begin{aligned}
& P_{-} f f(i)=f f(i+1)-f f(i) \\
& P_{-} k k(i)=k k(i+1)-k k(i) ; \\
& P_{-} s s(i)=s s(i+1)-s s(i), \quad i=1,2,3, \ldots, N-1 .
\end{aligned}
$$


Then for the obtained sequences of pseudo-differences we calculate the means: $m f=0.1119 ; m k=0.1274 ; m s=0.1734$.

Then for $\mathrm{i}=1,2,3$ using the heuristic formulae:

$$
\begin{aligned}
& f f(i)=f f(N-4+i)+1.2 m f+0.01 \cdot \operatorname{randn}(1,1) ; \\
& k k(i)=k k(N-4+i)+1.2 m k+0.01 \cdot \operatorname{randn}(1,1) ; \\
& s s(i)=s s(N-4+i)+1.2 m s+0.01 \cdot \operatorname{randn}(1,1) ;
\end{aligned}
$$

we generate three future values for each of the three factors $f f, k k$, ss.

Now everything is prepared for calculating the prediction estimates and filtered estimates using the Kalman filter equations and the model (11), (12).

The calculated predictions estimates and analyses of their quality for the three-factor non-linear regression model and the model in terms of SS are represented in Tables 3 and 4.

At first, we consider the accuracy of the labour productivity estimates based on the non-linear Cobb-Douglas model, then the same consideration for the estimates based on the linear stationary model in terms of SS. According to the model (2) the following estimates were obtained for the three future years. The estimates quality is measured by the absolute percentage error for the real and the calculated values (see Table 3 ).

Table 3

\begin{tabular}{|l|c|c|c|c|}
\hline \multirow{2}{*}{ Predictions } & \multicolumn{4}{|c|}{ Prediction for 3 years } \\
\cline { 2 - 5 } Indicators & $\begin{array}{c}\text { Element } \\
\text { No. 15 }((Y(15))\end{array}$ & $i$-th year & $(i+1)$-th year & $(i+2)$-th year \\
\hline Real data & 38723 & 33911 & 38101 & 42352 \\
\hline Predicted data & 38723 & 67835 & 76711 & 89064 \\
\hline Discrepancy & 0 & -33924 & -38610 & -46712 \\
\hline APE & $0 \%$ & $\approx 101 \%$ & $\approx 101.335 \%$ & $\approx 110.295 \%$ \\
\hline
\end{tabular}

Following the model (2) and using the real and predicted values the graphs of the estimates for the three future years are given in Fig. 3.

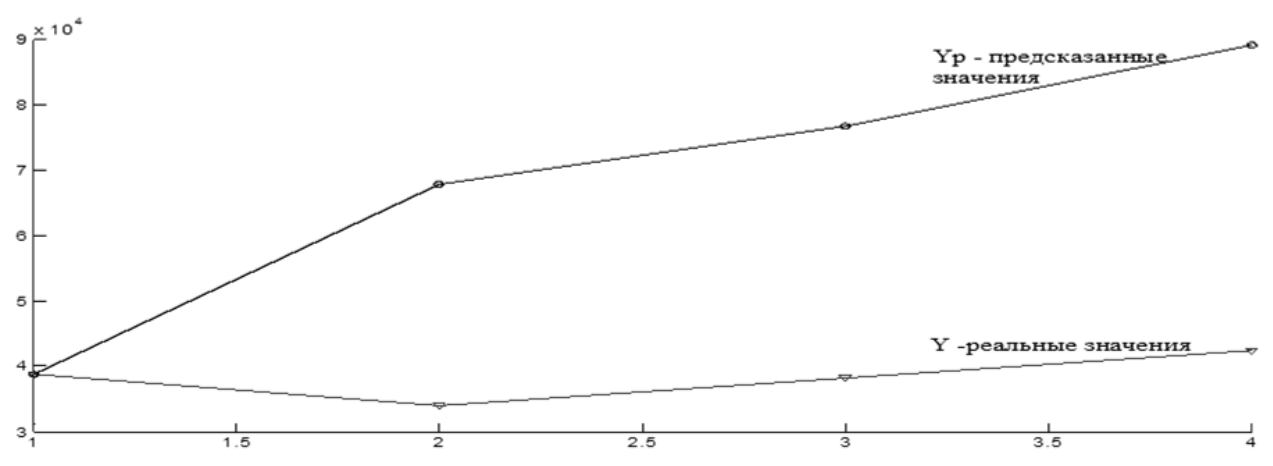

Fig. 3. Graphs based on the calculated values according to the three-factor Cobb-Douglas model:

1) $\{Y(i), i=1,2,3\}$ are the real observed data; 2$)\left\{Y_{p}(i), i=1,2,3\right\}$ are the predicted estimates for the initial conditions $Y(15)=Y_{p}(15)=38723$ 
Let now consider the quality of the prediction estimates and filtered estimates calculated, using the model in terms of SS for the 15 years long TS data, for three future years. The estimates quality is measured by the absolute percentage error for the real and the calculated values. All data are presented in Table 4.

Table 4

\begin{tabular}{|l|c|c|c|c|}
\hline \multirow{2}{*}{ Predictions } & \multicolumn{3}{|c|}{ Prediction for 3 years } \\
\cline { 2 - 5 } & $\begin{array}{c}Y(15)-\text { the } \\
\text { value for the } \\
15 \text {-th year }\end{array}$ & $i$-th year & $(i+1)$-th year & $(i+2)$-th year \\
\hline Real data $y\left(t_{i}\right)$ & 38723 & 33911 & 38101 & 42352 \\
\hline Predicted data $\hat{x}\left(t_{i+1} \mid t_{i}\right)$ & 38723 & 56997 & 56288 & 61271 \\
\hline $\begin{array}{l}\text { Discrepancy based on the esti- } \\
\text { mate } \hat{x}\left(t_{i+1} \mid t_{i}\right)\end{array}$ & 0 & -23086 & -18187 & -18919 \\
\hline APE & 0 & $\approx 68.078 \%$ & $\approx 47.734 \%$ & $\approx 44.671 \%$ \\
\hline Filtered estimate $\hat{x}\left(t_{i+1} \mid t_{i+1}\right)$ & 38723 & 46071 & 47987 & 52650 \\
\hline $\begin{array}{l}\text { Discrepancy based on the esti- } \\
\text { mate } \hat{x}\left(t_{i+1} \mid t_{i+1}\right)\end{array}$ & 0 & -12160 & -9886 & -10298 \\
\hline APE & $0 \%$ & $\approx 33.859 \%$ & $\approx 25.047 \%$ & $\approx 24.315 \%$ \\
\hline
\end{tabular}

Following the model (8), (9) and using the model in terms of SS the graphs of the estimates for the three future years are pictured on the fig. 4 for: 1) $\{Y(i), i=1,2,3\}$ the real observed data, $\left\{Y_{p}(i), i=1,2,3\right\}$ the predicted estimates and $\left\{Y_{f}(i), i=1,2,3\right\}$ the filtered estimates.

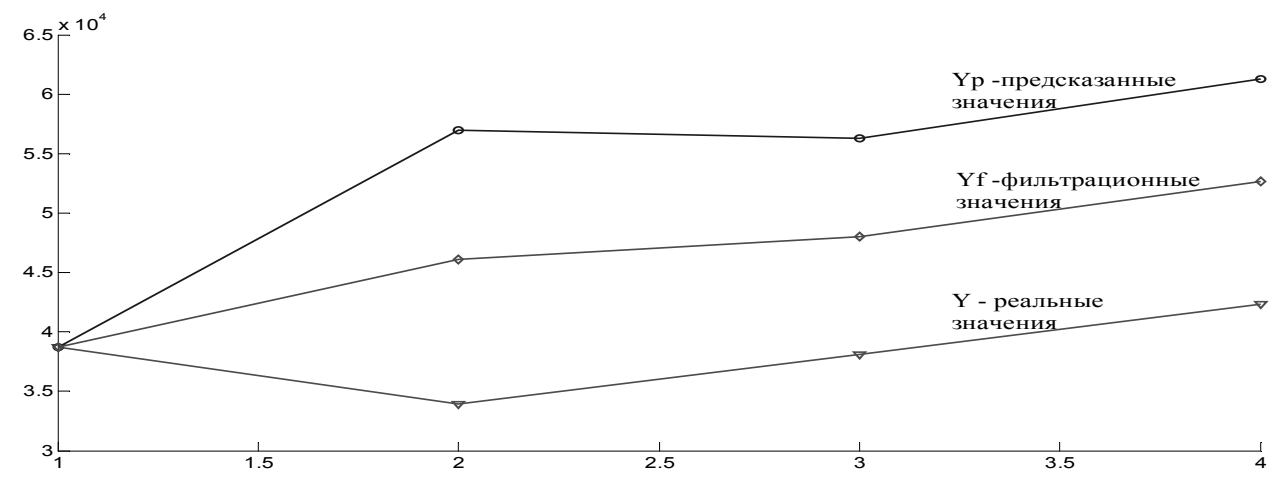

Fig. 4. Graphs based on the calculated values according to the model in terms of SS:

1) $\{Y(i), i=1,2,3\}$ are the real observed data; 2$)\left\{Y_{p}(i), i=1,2,3\right\}$ are the predicted estimates; 3) $\left\{Y_{f}(i), i=1,2,3\right\}$ are the filtered estimates for the initial conditions $x p(15)=x f(15)=Y(15)=38723$

We found that the TS predictions for the labour productivity obtained using the model in terms of SS are more accurate than the predictions obtained using the three-factor non-linear regression Cobb-Douglas model. The APEs for the threefactor Cobb-Douglas model are in the range from $101 \%$ to $110 \%$, whereas the APEs for the model in terms of SS go down from $68 \%$ to $44 \%$. The quality of the 
filtered estimates as the most reliable estimate is even better, the APEs go from $33 \%$ to $24.3 \%$.

The qualities of the predicted estimates were also measured using the Teil formula (4). The predicted estimates error coefficient calculated using the CobbDouglas formula (2) and the real TS data is $L_{1}=0.3438$.

The predicted estimates error coefficient calculated by the Teil formula (4) for the estimates obtained using the Kalman filter equations and the real data is $L_{2}=0.2091$, and the predicted estimates error coefficient calculated by the Teil formula (4) for the estimates obtained using the model in terms of SS, the Kalman filter equations and the real TS data is $L_{3}=0.1241$.

As one can see analyzing the estimates quality using the absolute percentage error and the Teil formula, the model in terms of SS provides more accurate prediction estimates and more reliable filtered estimates.

\section{CONCLUSION}

Economic science is the main tool for objective economic decision making and the quality of the decisions highly depends on the science level. There is no direct applicability of economic models in economic practice, the reasons for that were for the first time systematically described in [10]. At the same time despite the "impracticalness" of such models they strongly influence the economic way of thinking and the choice of an economic policy of an enterprise or a country.

The proposed linear stationary model in terms of SS allows calculating the industrial production yield dynamics behaviour in terms of cost as the one of the significant key economic factors, the yield being dependent on the capital-labour ratio, amount of the labour force engaged in the production and the labour costs. The model has the minimal degree of uncertainty, similar to the three-factor industrial Cobb-Douglas model, concerning unaccounted factors and high adequacy concerning the statistical data used. The model takes into account the stochastic nature of TS statistical data and the effect of each factor on the dynamics of the industrial production yield in terms of cost.

Thus, the model in terms of SS can be more efficient than the three-factor Cobb-Douglas model for predicting the goods and services production dynamics in regional and branch levels.

\section{REFERENCES}

1. Maevskii V.V., Kharin Yu.S. Robastnost' regressionnogo prognozirovaniya pri nalichii funktsional'nykh iskazhenii modeli [Robust regressive forecasting under functional distortions in a model] Avtomatika i telemekhanika - Automation and Remote Control, 2012, no. 11, pp. 118-137. (In Russian).

2. Kravtsov Yu.N. Sluchainost', determinirovannost', predskazuemost' [Accident, determinism, predictability]. Uspekhi fizicheskikh nauk - Soviet Physics Uspekhi, 1989, vol. 158, iss. 1, pp. 93-122. (In Russian).

3. Kropotov Yu.F., Ermolaev V.A., Eremenko W.T., Korasev O.E. Determining the number of parameters. Journal of Communications and Electronics, 2010, vol. 55, iss. 1, pp. 52-57.

4. Proskuryakov A.Yu., Belov A.A., Kropotov Yu.A. Algoritm avtomatizirovannykh sistem ekologicheskogo monitoringa promyshlennykh proizvodstv [Algorithm of automated systems for environmental monitoring of industrial production]. Moscow, Berlin, Direct Media Publ., 2015. 121 p. 
5. Ermolaev V.A. O metodakh prognozirovaniya vremennykh ryadov i nepreryvnykh protsessov [On the methods of forecasting time series and continuous processes]. Radiotekhnicheskie i telekommunikatsionnye sistemy - Radio and telecommunication systems, 2016, no. 2, pp. 52-63.

6. Buravlev A.I. Trekhfaktornaya proizvodstvennaya model' Kobba-Duglasa [Three-factor production model of Cobb-Douglas]. Ekonomika i upravlenie: problemy, resheniya, 2012, no. 3, pp. 13-19.

7. Belov A.A., Proskuryakov A.Yu. Voprosy otsenivaniya kachestva prognozirovaniya vremennykh ryadov [Issues of assessing the quality of forecasting time series]. Metody i ustroistva peredachi $i$ obrabotki informatsii - Methods and devices of information transmission and processing, 2011, iss. 13, pp. 105-108.

8. Ivanilov Yu.P., Lotov A.V. Matematicheskie modeli v ekonomike [Mathematical models in economics]. Moscow, Nauka Publ., 1979. 304 p.

9. Rossiya v tsifrakh [Russia in numbers]. Moscow, Rosstat Publ., 2009. 525 p.

10. Abdenova G.A. Prognozirovanie znachenii urovnya vremennogo ryada na osnove uravnenii fil'tra Kalmana [Predicting the values of the time series level based on the Kalman filter equations]. Polzunovskii vestnik - Polzunov Bulletin, 2010, no. 2, pp. 4-6.

11. Sinitsyn I.N. Fil'try Kalmana i Pugacheva [Kalman and Pugachev filters]. Moscow, Universitetskaya kniga Publ., Logos Publ., 2006. 640 p.

12. Peredumov V.P. Ob ustoichivosti modelirovaniya na TsVM lineinykh dinamicheskikh sistem [On the stability of modeling on digital computers of linear dynamic systems]. Vestnik Kievskogo politekhnicheskogo institute. Tekhnicheskaya kibernetika [Herald Kiev Polytechnic Institute. Technical cybernetics]. Kiev, Vishcha shkola Publ., 1983, iss. 7, pp. 39-41.

13. Yusupova M.D. Proizvodstvennaya funktsiya Kobba-Duglasa, kak instrument analiza matematicheskikh modelei [The Cobb-Douglas production function, as a tool for analyzing mathematical models]. Izvestiya Chechenskogo gosudarstvennogo pedagogicheskogo universiteta - Proceedings of the Chechen State Pedagogical University, 2017, vol. 17, no. 4 (20), pp. 304-309.

14. Eykhoff P. System identification: parameter and state estimation. London, John Wiley \& Sons, 1974. 555 p. (Russ. ed.: Eikhoff P. Osnovy identifikatsii sistem upravleniya: otsenivanie parametrov i sostoyaniya. Translated from English. Moscow, Mir Publ., 1975. 683 p.).

15. Mehra R. Identification and adaptive Kalman filtering. Mechanics, 1971, no. 3, pp. 34-52.

16. Brammer K., Ziffling G. Fil'tr Kalmana-B'yusi: determinirovannoe nablyudenie $i$ stokhasticheskaya fil'tratsiya [Kalman-Bucy Filter: deterministic observation and stochastic filtering]. Moscow, Nauka Publ., 1982.199 p. (In Russian).

17. Kleiner G.B. Ekonomiko-matematicheskoe modelirovanie i ekonomicheskaya teoriya [Economic-mathematical modeling and economic theory]. Ekonomika i matematicheskie metody - Economics and Mathematical Methods, 2001, vol. 37, no. 3, pp. 3-25.

Abdenov Amirza Zhakenovich, professor, D. Sc (Eng.), Professor at the Information Systems Department in the L.N. Gumilyov Eurasian National University. His scientific interests cover mathematical modeling of stochastic objects behavior and information security. He is the author of 1 monograph and more than 250 scientific publications and teaching manuals. Email: amirlan21@gmail.com

Abdenova Aliya Amirzaevna, a postgraduate student at the department of mathematical and computer modeling in the L.N. Gumilyov Eurasian National University. Her scientific interests include mathematical modeling of stochastic objects behavior and information security. She is the author of 7 scientific papers and teaching manuals. Email: aliyastana@gmail.com

Mukhanova Ayagoz Asanbekovna, PhD (Eng.), an acting associate professor at the Department of Information Systems in the L.N. Gumilyov Eurasian National University. Her scientific interests are focused on mathematical modeling of stochastic objects behavior and information security. She is the author of 18 scientific papers and teaching manuals. E-mail: ayagoz198302@mail.ru 
Абденов Амирза Жакенович, профессор, доктор технических наук, профессор кафедры информационных систем Евразийского национального университета им. Л.Н. Гумилева. Научные интересы - математическое моделирование поведения стохастических объектов и информационная безопасность. Автор 250 научных и методических работ и одной монографии. E-mail: amirlan21@gmail.com

Абденова Алия Амирзаевна, соискатель кафедры математического и компьютерного моделирования Евразийского национального университета им. Л.Н. Гумилева. Научные интересы - математическое моделирование поведения стохастических объектов. Автор семи научно-методических работ. E-mail: aliyastana@gmail.com

Муханова Аягоз Асанбековна, кандидат технических наук, исполняющий обязанности доцента кафедры информационных систем Евразийского национального университета им. Л.Н. Гумилева. Научные интересы - математическое моделирование поведения стохастических объектов и информационная безопасность. Автор 18 научно-методических работ. E-mail: ayagoz198302@mail.ru

DOI: $10.17212 / 1814-1196-2018-4-7-26$

\title{
Алгоритмы расчета оценок предсказаний производительности труда на основе регрессионных и динамических моделей*
}

\author{
АБДЕНОВ А.Ж. ${ }^{a}$, АБДЕНОВА А.A. ${ }^{b}$, МУХАНОВА А.A. ${ }^{c}$ \\ 010000, Казахстан, Астана, ул. Сатпаева, 2, Евразийский национальный университет \\ aamirlan21@gmail.com baliyastana@gmail.com cayagoz198302@mail.ru
}

Валовой внутренний продукт - один из важнейших показателей системы национальных счетов, который характеризует конечный результат производительной деятельности экономических единиц-резидентов и измеряет стоимость товаров и услуг, произведенных этими единицами внутри страны за определенный период времени для конечного использования. В статье рассматривается алгоритм построения линейной стационарной модели в форме пространства состояний для описания поведения и предсказания состояния производительности труда в зависимости от факторов фондовооруженности и величины оплаты труда работников взамен описанию объекта, которая задана в виде трехфакторной нелинейной регрессионной модели Кобба-Дугласа. В алгоритме, кроме общего построения динамической стохастической модели, содержится описание процедур в виде рекуррентных формул, позволяющих рассчитать величины дисперсий шумов динамики, шумов измерительной системы и начального состояния поведения исследуемого объекта на основе временных рядов выхода статистических данных производительности труда. На примере показано, что построенная динамическая модель дает более эффективные оценки предсказания величин производительности труда по сравнению с оценками предсказания, рассчитанными на основе трехфакторной нелинейной регрессионной модели. Приведен численный расчет качества точности оценок предсказаний, полученных с помощью трехфакторной формулы Кобба-Дугласа и модели в форме пространства состояний на основе абсолютной процентной ошибки и формулы Тейла. Расчетные данные указывают на более точные оценки предсказания и более достоверные оценки фильтрации в пользу модели в форме пространства состояний.

Ключевые слова: модель Кобба-Дугласа, трехфакторная модель, динамическая модель, пространство состояний, дисперсии шумов, фильтр Калмана, абсолютная процентная ошибка, формула Тейла

\footnotetext{
* Статья получена 22 февраля 2018 г.
} 


\section{СПИСОК ЛИТЕРАТУРЫ}

1. Маевский В.В., Харин Ю.С. Робастность регрессионного прогнозирования при наличии функциональных искажений модели // Автоматика и телемеханика. - 2012. - № 11. - С. 118-137.

2. Кравиов Ю.Н. Случайность, детерминированность, предсказуемость // Успехи физических наук. - 1989. - Т. 158, вып. 1. - С. 93-122.

3. Identification of models for discrete linear systems with variable, slowly varying parameters / Yu.F. Kropotov, V.A. Ermolaev, W.T. Eremenko, O.E. Korasev // Journal of Communications and Electronics. -2010 . - Vol. 55, iss. 1. - P. 52-57.

4. Проскуряков А.Ю., Белов А.А., Кропотов Ю.А. Алгоритм автоматизированных систем экологического мониторинга промышленных производств: монография. - М.; Берлин: ДиректМедиа, 2015. - $121 \mathrm{c}$.

5. Ермолаев В.А. О методах прогнозирования временных рядов и непрерывных процессов // Радиотехнические и телекоммуникационные системы. - 2016. - № 2. - С. 52-63.

6. Буравлев А.И. Трехфакторная производственная модель Кобба-Дугласа // Экономика и управление: проблемы, решения. - 2012. - № 3. - С. 13-19.

7. Белов А.А., Проскуряков А.Ю. Вопросы оценивания качества прогнозирования временных рядов // Методы и устройства передачи и обработки информации. - 2011. - Вып. 13. C. $105-108$. $304 \mathrm{c}$.

8. Иванилов Ю.П., Лотов А.В. Математические модели в экономике. - М.: Наука, 1979. -

9. Россия в цифрах. - М.: Росстат, 2009. - 525 с.

10. Абденова Г.А. Прогнозирование значений уровня временного ряда на основе уравнений фильтра Калмана // Ползуновский вестник. - 2010. - № 2. - С. 4-6.

11. Синицьıн И.Н. Фильтры Калмана и Пугачева. - М.: Университетская книга: Логос, 2006. $-640 \mathrm{c}$.

12. Передумов В.П. Об устойчивости моделирования на ЦВМ линейных динамических систем // Вестник Киевского политехнического института. - Киев: Вища школа, 1983. - Вып. 7. С. 39-41. - (Техническая кибернетика).

13. Юсупова М.Д. Производственная функция Кобба-Дугласа как инструмент анализа математических моделей // Известия Чеченского государственного педагогического университета. - 2017. - Т. 17, № 4 (20). - С. 304-309.

14. Эйкхофф П. Основы идентификации систем управления: оценивание параметров и состояния. - М.: Мир, 1975. - 683 с.

15. Mehra R. Identification and adaptive Kalman filtering // Mechanics. - 1971. - N 3. - P. 34-52.

16. Браммер K., Зиффлинг Г. Фильтр Калмана-Бьюси: детерминированное наблюдение и стохастическая фильтрация. - М.: Наука, 1982. - 199 с.

17. Клейнер Г.Б. Экономико-математическое моделирование и экономическая теория // Экономика и математические методы. - 2001. - Т. 37, № 3. - С. 3-25.

For citation:

Abdenov A.Zh., Abdenova A.A., Mukhanova A.A. Algoritmy rascheta otsenok predskazanii proizvoditel'nosti truda na osnove regressionnykh i dinamicheskikh modelei [Algorithms for estimating labour productivity prediction based on regression and dynamic models]. Nauchnyi vestnik Novosibirskogo gosudarstvennogo tekhnicheskogo universiteta - Science bulletin of the Novosibirsk state technical university, 2018, no. 4 (73), pp. 7-26. doi: 10.17212/1814-1196-2018-4-7-26.

Для цитирования:

Абденов А.Ж., Абденова А.А., Муханова А.А. Алгоритмы расчета оценок предсказаний производительности труда на основе регрессионных и динамических моделей // Научный вестник НГТУ. - 2018. - № 4 (73). - С. 7-26. - Яз. англ. - doi: 10.17212/1814-1196-2018-4-7-26.

ISSN 1814-1196, http://journals.nstu.ru/vestnik Science Bulletin of the NSTU Vol. 73, No 4, 2018, pp. 7-26 